\title{
Pengaruh Green Marketing dan Service Quality terhadap Loyalitas Pelanggan dengan Customer Satisfaction sebagai Variabel Intervening (Studi Kasus di Starbucks Coffee Kota Surabaya)
}

\author{
Effect of Green Marketing and Service Quality on Customer Loyalty \\ with Customer Satisfaction as Intervening Variable \\ (Case Study at Starbucks Coffee Surabaya City)
}

\author{
Dwitriana Ulfi Rizqiningsih $^{1)}$, Arry Widodo ${ }^{2)}$ \\ ${ }^{1,2)}$ Faculty of Communication and Business, Telkom University, Kota Bandung \\ e-mail korespondensi: dwitrianaur@student.telkomuniversity.ac.id
}

\begin{tabular}{|c|c|}
\hline Info Artikel & Abstrak \\
\hline $\begin{array}{l}\text { Riwayat Artikel: } \\
\text { Diterima: } 18 \text { Maret } 2021 \\
\text { Disetujui: } 17 \text { Juli } 2021 \\
\text { Dipublikasikan: Juli } 2021\end{array}$ & $\begin{array}{l}\text { Penelitian ini bertujuan untuk mengetahui pengaruh dari green marketing dan } \\
\text { service quality terhadap loyalitas pelanggan melalui customer safisfaction } \\
\text { sebagai variabel intervening. Dalam proses analisis, penelitian ini mengaplikasi- } \\
\text { kan studi kasus pada Starbucks Coffee sebagai salah satu bisnis yang }\end{array}$ \\
\hline $\begin{array}{l}\text { Nomor DOI } \\
\text { 10.33059/jseb.v12i2.3351 } \\
\text { Cara Mensitasi : } \\
\text { Rizqiningsih, D. U., \& Widodo, } \\
\text { A. (2021). Pengaruh green } \\
\text { marketing dan service quality } \\
\text { terhadap loyalitas pelanggan } \\
\text { dengan customer satisfaction } \\
\text { sebagai variabel intervening } \\
\text { (Studi kasus di Starbucks } \\
\text { Coffee Kota Surabaya). Jurnal } \\
\text { Samudra Ekonomi dan Bisnis, } \\
\text { 12(2), 242-256. doi: } \\
\text { 10.33059/jseb. v12i2.3351. }\end{array}$ & $\begin{array}{l}\text { menerapkan strategi green marketing. Metode yang digunakan berparadigma } \\
\text { kuantitatif dengan jenis penelitian deskriptif dan kausalitas, serta metode analisis } \\
\text { SEM-PLS. Teknik nonprobability sampling digunakan untuk memilih sampel } \\
\text { sebanyak } 385 \text { pelanggan Starbucks Coffee di Kota Surabaya. Berdasarkan hasil } \\
\text { penelitian disimpulkan bahwa green marketing dan service quality berpengaruh } \\
\text { positif dan signifikan terhadap loyalitas pelanggan baik secara langsung maupun } \\
\text { melalui customer satisfaction sebagai variabel intervening. } \\
\text { Kata Kunci: Green Marketing, Service Quality, Loyalitas Pelanggan, Customer } \\
\text { Satisfaction. }\end{array}$ \\
\hline
\end{tabular}

\begin{tabular}{|c|c|}
\hline Article Info & Abstract \\
\hline $\begin{array}{l}\text { Article History : } \\
\text { Received: } 18 \text { March } 2021 \\
\text { Accepted: } 17 \text { July } 2021 \\
\text { Published: July } 2021\end{array}$ & $\begin{array}{l}\text { This study aims to determine the effect of green marketing and service quality } \\
\text { on customer loyalty through customer satisfaction as an intervening variable. In } \\
\text { the analysis process, this research applies a case study on Starbucks Coffee as } \\
\text { a business that implements a green marketing strategy. The method used is a }\end{array}$ \\
\hline $\begin{array}{l}\text { DOI Number : } \\
\text { 10.33059/jseb.v12i2.3351 } \\
\text { How to cite : } \\
\text { Rizqiningsih, D. U., \& Widodo, } \\
\text { A. (2021). Pengaruh green } \\
\text { marketing dan service quality } \\
\text { terhadap loyalitas pelanggan } \\
\text { dengan customer satisfaction } \\
\text { sebagai variabel intervening } \\
\text { (Studi kasus di Starbucks } \\
\text { Coffee Kota Surabaya). Jurnal } \\
\text { Samudra Ekonomi dan Bisnis, } \\
\text { 12(2), 242-256. doi: } \\
\text { 10.33059/jseb. v12i2.3351. }\end{array}$ & $\begin{array}{l}\text { quantitative paradigm with descriptive and causal research types, as well as the } \\
\text { SEM-PLS analysis method. Non-probability sampling technique was used to } \\
\text { select a sample of } 385 \text { Starbucks Coffee customers in Surabaya City. Based on } \\
\text { the results, it was concluded that green marketing and service quality had a } \\
\text { positive and significant effect on customer loyalty either directly or through } \\
\text { customer satisfaction as an intervening variable. } \\
\text { Keywords: Green Marketing, Service Quality, Customer Loyalty, Customer } \\
\text { Satisfaction. }\end{array}$ \\
\hline
\end{tabular}




\section{PENDAHULUAN}

Topik trending saat ini yaitu masalah sampah, utamanya sampah plastik, yang dinilai memperburuk pemanasan global dan berdampak negatif atas kesehatan biologis dan perubahan iklim. (Ambari, 2020; Browne et al., 2013). Secara khusus, The World Bank 2019 menyebutkan setiap hari Indonesia menghasilkan sekitar 24.500 ton plastik per hari. Kondisi ini diproyeksikan pada tahun 2025 dihasilkan sekitar 9 juta ton sampah plastik (BPS, 2019). Sikap ketidakpedulian manusia yang berlebihan mengeksploitasi lingkungan untuk memenuhi kebutuhannya menyebabkan polusi sampah plastik skala besar dan akhirnya menyebabkan perubahan iklim dan mengganggu keharmonisan dalam lingkungan (Dohong, 2020; Chandra, 2020).

Pada situasi tersebut diindikasi sebagian besar penyumbang sampah berada dalam industri makanan dan minuman (Rasyadi, 2019). Peningkatan industri minuman yang signifikan tentu menghasilkan pertumbuhan jumlah sampah plastik yang juga semakin meningkat karena industri tersebut terus bergantung pada kemasan plastik sekali pakai. Situasi ini akhirnya mendorong semakin banyak bisnis yang berusaha keras untuk memanfaatkan potensi kepedulian lingkungan untuk operasi bisnis sebagai tanggapan atas kepedulian publik yang berkembang terhadap lingkungan dengan mulai memasarkan produk atau layanan jasa yang lebih sehat bagi pelanggan dan ramah lingkungan. Upaya perusahaan mengaplikasikan permasalahan lingkungan dalam aktivitas pemasarannya menimbulkan fenomena baru berupa konsep green marketing (pemasaran hijau).

Green marketing merupakan strategi perusahaan untuk memasarkan produk dengan cara yang ramah lingkungan dalam aktivitas pemasarannya, seperti memodifikasi produk, mengubah kemasan, menyesuaikan proses produksi, serta bahkan mengubah metode promosi (Sandeen, 2009; Irkhamni et al., 2017). Strategi ini dinilai dapat membantu perusahaan dalam membangun keunggulan kompetitif dengan menciptakan imej 'ramah lingkungan' di persepsi konsumen sehingga meningkatkan loyalitas pelanggannya (Sari \& Setiawan, 2017).

Penelitian ini berfokus pada Starbucks Kota Surabaya karena beberapa alasan (Starbucks, 2020; Irwansyah, 2015). Pertama, Starbucks Coffee merupakan salah satu bisnis yang menerapkan strategi green marketing dan dikenal kontribusinya pada lingkungan seperti pembuangan limbah yang tepat, mengurangi gelas/cup sekali pakai, serta mengganti kemasan dengan tumbler untuk meminimalkan dan mendaur ulang kemasan makanan. Kedua, Kota Surabaya merupakan kota kedua dengan jumlah gerai Starbucks Coffee terbanyak yaitu 27 gerai, sehingga memudahkan perusahaan ini menyampaikan awareness dan edukasi tentang produkproduknya yang ramah lingkungan kepada konsumen. Temuan riset Wicaksana (2014) menilai loyalitas pelanggan Starbucks di Kota Surabaya memiliki persentase tinggi dan dikategorikan sebagai satisfied buyer.

Selain penerapan green marketing, loyalitas pelanggan atas produk perusahaan bisa diciptakan melalui pemberian service quality yang berkualitas (Zeithaml et al., 1996; Kotler \& Keller, 2016). Loyalitas pelanggan terbentuk atas perusahaan yang dianggap memberikan nilai (value) kualitas paling besar (Parasuraman et al., 1985; Kotler $\&$ Armstrong, 2017). Pembentukan service quality berkualitas oleh perusahaan dalam lingkungan yang kompetitif saat ini adalah strategi penting untuk kesuksesan dan kelangsungan hidup serta pada akhirnya dapat menciptakan loyalitas pelanggan yang tinggi.

Faktor terakhir yang diidentifikasi mempengaruhi konsumen menjadi loyal adalah berasal dari kepuasan pelanggan. Customer 
satisfaction adalah penilaian atas layanan yang diberikan oleh konsumen berdasarkan kualitas layanan dan pengalaman dirinya saat melakukan pembelian suatu barang atau jasa (Kotler \& Armstrong, 2017; Tjiptono, 2014). Capaian tingkatan customer satisfaction terindikasi juga dipengaruhi oleh strategi green marketing ataupun service quality yang diterapkan perusahaan terkait. Hal ini sebagai konsekuensi sikap konsumen yang seringkali memperbandingkan antara harapan yang dimiliki dan ingin dipenuhinya dengan kinerja layanan yang diberikan perusahaan untuk memenuhi harapannya tersebut (Fida et al., 2020; Malau, 2017). Apabila merasakan satisfaction berkenaan dengan aspek-aspek green marketing ataupun service quality maka konsumen dinilai akan loyal dan bersedia melakukan transaksi pembelian kembali pada perusahaan tersebut.

Penelitian ini bertujuan melakukan identifikasi atas arah dan derajat signifikansi dari pengaruh green marketing dan service quality terhadap loyalitas pelanggan, baik secara langsung ataupun melalui customer satisfaction sebagai variabel intervening. Hasil-hasil empiris yang diperoleh dalam penelitian ini diekspektasi dapat membantu perusahaan mengembangkan strategi green marketing serta meningkatkan service quality yang diberikannya.

\section{Loyalitas Pelanggan}

Loyalitas pelanggan merupakan bentuk motivasi perilaku untuk melakukan pembelian berulang. Loyalitas bisa didefinisikan sebagai bentuk kewajiban yang dipegang teguh oleh seorang pelanggan untuk membeli atau berlangganan kembali ke produk atau layanan tertentu di masa depan, terlepas dari dampak situasi dan aktivitas pemasaran yang berpotensi menyebabkan perubahan perilaku (Kotler \& Keller, 2016; Tjiptono, 2014). Karenanya proses untuk membangun loyalitas pelanggan terhadap suatu produk atau jasa yang dihasilkan oleh pelaku usaha atau perusahaan membutuhkan waktu lama (Peter \& Olson, 2010; Kotler \& Armstrong, 2017).

Loyalitas dapat dipahami dalam dua dimensi (Bennett \& Bove, 2002; Saini \& Singh, 2020). Dimensi pertama adalah aliran behavioral loyalty, artinya loyalitas dapat dipahami sebagai konsep yang menentukan urutan pembelian, proporsi pembelian, dan probabilitas pembelian. Dimensi kedua adalah aliran attitudinal loyalty, artinya kesetiaan dipahami sebagai suatu bentuk keterikatan psikologis pada objek.

Terdapat enam indikator yang dapat digunakan mengukur loyalitas konsumen (Sumarwan et al., 2011), yaitu: (1) pembelian kembali (repeat purchase); (2) ketahanan mengkonsumsi merek tersebut; (3) selalu suka pada merek tersebut; (4) tetap memilih merek tersebut; (5) keyakinan bahwa merek tersebut adalah yang terbaik; dan, (6) merekomendasikan merek tersebut kepada orang lain. Apabila keenam indikator ini terpenuhi maka pelanggan bersangkutan dinilai memiliki level loyalitas yanng sangat tinggi.

\section{Green Marketing}

Green marketing adalah keseluruhan proses manajemen yang bertanggungjawab melakukan identifikasi, memprediksi serta memuaskan berbagai kebutuhan konsumen dan masyarakat dengan cara menguntungkan dan berkelanjutan, serta melibatkan manfaatmanfaat sosio-ekonomi dan tanggungjawab lingkungan yang dibawa oleh perusahaan bersangkutan (Sandeen, 2009; Irkhamni \& Suharyono, 2017; Alhamad et al., 2019). Penerapan green marketing memiliki tujuan menghasilkan produk ramah lingkungan, pemenuhan harapan dan kebutuhan konsumen yang sadar lingkungan, serta inovasi produk mulai dari segi input, proses, hingga produksi, bahkan strategi pemasaran. 
Dalam bukunya, Grant (2007) membagi tujuan green marketing menjadi tiga tahap: (1) Green yang bertujuan menyampaikan kepedulian merek atau perusahaan terhadap lingkungan; (2) Greener dimana perusahaan berusaha mengubah gaya konsumsi atau penggunaan produk oleh konsumen seperti menggunakan kertas bekas atau daur ulang, menghemat air, listrik, menggunakan $\mathrm{AC}$, dan lainnya; serta, (3) Greenest yaitu perusahaan terhijau sedang mencoba mengubah budaya konsumen menuju budaya yang lebih ramah lingkungan.

Beberapa temuan empiris terdahulu (Martinez, 2015; Sari \& Setiawan, 2017; Jabeen \& Kavitha, 2020) menemukan bahwa penerapan strategi green marketing memiliki pengaruh yang bersifat positif dan signifikan dalam menumbuhkan sikap loyal pelanggan kepada perusahaan yang mengaplikasikan strategi itu. Nilai yang positif menunjukkan bahwa jika green marketing semakin intensif diterapkan maka loyalitas konsumen terhadap produk tertentu akan meningkat; sebaliknya, jika semakin buruk strategi green marketing yang diterapkan maka loyalitas konsumen terhadap produk tersebut akan menurun. Demikian demikian, hipotesis pertama yang diajukan dalam penelitian ini adalah:

H1: Green marketing memiliki pengaruh yang signifikan terhadap loyalitas pelanggan Starbucks Coffee di Kota Surabaya.

\section{Service Quality}

Dalam memuaskan pelanggan, selain produk yang aman dan nyaman digunakan, layanan yang diberikan oleh perusahaan harus berkualitas tinggi. Kualitas pelayanan atau service quality didefinisikan selaku seberapa jauh perbandingan antara realitas serta harapan pelanggan atas layanan yang mereka terima (Malau, 2017). Untuk menyediakan layanan berkualitas tinggi dalam upaya mempromosikan penjualan layanan dan menciptakan keunggulan unik di antara pesaing, service quality seharusnya dimulai dengan kebutuhan pelanggan dan persepsi pelanggan (Tjiptono, 2014; Kotler \& Keller, 2016). Dengan demikian, perusahaan akan dinilai memiliki service quality berkualitas tinggi jika memenuhi harapan pelanggannya.

Sejumlah peneliti sebelumnya telah berupaya mengidentifikasi hubungan antara service quality dan loyalitas pelanggan. Hasil riset Fida et al. (2020) menemukan bahwa meningkatnya service quality yang diberikan suatu perusahaan memberi dampak signifikan untuk mempertinggi loyalitas pelanggan dari perusahaan tersebut. Demikian juga, temuan studi milik Pereira et al. (2016) maupun Narotama (2019) menyatakan service quality berpengaruh positif signifikan atas loyalitas pelanggan, sehingga dinyatakan service quality memegang peran penting dalam menciptakan loyalitas pelanggan. Demikian demikian, hipotesis kedua yang diajukan adalah:

H2: Service quality memiliki pengaruh yang signifikan terhadap loyalitas pelanggan Starbucks Coffee di Kota Surabaya.

\section{Customer Satisfaction}

Customer satisfaction atau kepuasan pelanggan adalah perasaan senang atau kecewa yang dimiliki seseorang karena membandingkan fakta yang diperoleh dengan harapan pelanggan (Priansa, 2017; Kotler \& Keller, 2016; Tsai \& Chen, 2007). Jika barang dan jasa dibeli oleh konsumen sesuai harapan dirinya, maka konsumen itu akan merasa puas; sebaliknya, jika kinerja tidak sesuai harapan maka konsumen tersebut akan merasa tidak puas. Hubungan antara kepuasan dan loyalitas adalah saat konsumen mencapai kepuasan tertinggi, yang menghasilkan ikatan emosional yang kuat dan komitmen jangka panjang atas merek perusahaan. 
Beberapa peneliti terdahulu (Özkan et al., 2020; Alfin \& Nurdin, 2017; Nuraeni et al., 2019) memperoleh hasil bahwa kepuasan konsumen berpengaruh positif terhadap loyalitas konsumen. Temuan ini menyatakan bahwa semakin puas konsumen setelah menggunakan suatu barang atau jasa, maka semakin tinggi loyalitas yang tercipta dalam diri pelanggan atas barang atau jasa tersebut.

Namun demikian, studi milik Soelasih (2017) sebaliknya menunjukkan customer satisfaction tidak berpengaruh terhadap loyalitas pelanggan. Argumen yang dimunculkan bahwa walaupun konsumen merasa puas namun belum tentu akan mampu menarik konsumen tersebut untuk setia menggunakan produk tertentu karena banyaknya variasi produk yang ditawarkan. Dengan demikian, terdapat gap riset yang menarik mengenai hubungan antara customer satisfaction terhadap loyalitas pelanggan. Karenanya, hipotesis ketiga yang diajukan adalah:

H3: Customer satisfaction mempunyai pengaruh yang signifikan terhadap loyalitas pelanggan Starbucks Coffee di Kota Surabaya.

Customer satisfaction diidentifikasi memiliki hubungan dengan green marketing oleh sejumlah penelitian terdahulu. Hasil empiris yang didapatkan oleh Irkhamni \& Suharyono (2017), Parlan et al. (2016) serta Eneizan \& Wahab (2016) menunjukkan green marketing berpengaruh positif dan signifikan terhadap customer satisfaction. Berdasarkan hasil riset terdahulu, hipotesis keempat yang diajukan adalah:

H4: Green marketing mempunyai pengaruh yang signifikan terhadap customer satisfaction Starbucks Coffee di Kota Surabaya.

Customer satisfaction juga diidentifikasi memiliki hubungan dengan service quality.
Tjiptono (2014) berargumen penentu utama kepuasan pelanggan adalah persepsi mereka tentang kualitas layanan. Hal ini sejalan dengan hasil penelitian Fida et al. (2020), Jimanto (2014) serta Özkan et al. (2020) yang menemukan service quality berpengaruh positif atas customer satisfaction. Berkenaan pemikiran ini, maka dimunculkan hipotesis kelima yang diajukan yaitu:

H5: Service quality mempunyai pengaruh yang signifikan terhadap customer satisfaction Starbucks Coffee di Kota Surabaya.

Secara khusus, customer satisfaction diidentifikasi pada satu sisi mempengaruhi loyalitas pelanggan, namun di sisi lain dipengaruhi oleh strategi green marketing dan servce quality. Karenanya pada penelitian ini dikembangkan sebagai variabel intervening. Dengan demikian, dimunculkan hipotesis keenam dan ketujuh berikut:

H6: Terdapat pengaruh positif oleh green marketing terhadap loyalitas pelanggan yang dimediasi customer satisfaction pada pelanggan Starbucks Coffee di Kota Surabaya.

H7: Terdapat pengaruh positif oleh service quality terhadap loyalitas pelanggan yang dimediasi customer satisfaction pada pelanggan Starbucks Coffee di Kota Surabaya.

\section{METODE PENELITIAN}

Penelitian kuantitatif dengn filosofi positivis ini bertujuan untuk menganalisis efek kausalitas atau konklusif (Indrawan \& Yuniawati, 2017; Sugiyono, 2018). Penelitian ini juga bersifat korelasional dan dirancang untuk mengumpulkan data cross sectional (Indrawati, 2015).

Variabel eksogen yang dianalisis terdiri atas green marketing (X1) dan service quality (X2); variabel endogen adalah loyalitas 
pelanggan (Y); serta, variabel intervening atau mediasi yang juga memiliki peran serupa variabel eksogen dalam penelitian ini adalah customer satisfaction (M). Pengukuran atas masing-masing variabel ini menggunakan skala ordinal untuk menentukan peringkat construct yang diukur (Sugiyono, 2018). Skala instrumen adalah skala Likert yang digunakan untuk mengukur fenomena sosial tertentu seperti sikap, pendapat dan persepsi sosial seseorang atau sekelompok orang (Hasan, 2002; Indrawan \& Yaniawati, 2017). Skala Likert dimulai dari skor 5 untuk pilihan jawaban "Sangat Setuju" sampai skor 1 untuk jawaban "Sangat Tidak Setuju".

\section{Populasi dan Sampel}

Populasi dalam penelitian ini adalah masyarakat kota Surabaya yang suka nongkrong atau lebih produktif dengan tahun kelahiran 1997-2012, yang presentasenya mencapai $25,79 \%$ dari jumlah penduduk kota Surabaya sebanyak 2.874.314 jiwa tahun 2020 (BPS Statistik, 2020).

Dari populasi itu, selanjutnya dipilih sampel yaitu sebagian dari Generasi Z di kota Surabaya. Pengambilan sampel menggunakan teknik nonprobability sampling, yaitu pengambilan sampel yang disengaja (purposive) dan subjektif berdasarkan pertimbangan tertentu (Indrawan \& Yuniawati, 2017).

Teknik random sampling digunakan saat penentuan responden sepanjang sesuai dengan kriteria yang ditentukan peneliti, yaitu: (a) masyarakat Kota Surabaya dalam rentang berusia 18-24 tahun; (b) pernah berkunjung pada Starbucks Coffee Kota Surabaya; (c) mengkonsumsi Starbucks Coffee Kota Surabaya dalam rentang waktu kurang lebih sebulan. Setelah dilakukan perhitungan menggunakan rumus Bernoulli, diperoleh jumlah responden sebanyak 385 orang (Zikmund et al., 2010).

\section{Pengumpulan Data}

Penelitian ini menggunakan sumber data primer berbasis survei yang dikumpulkan secara langsung pada responden (Jogiyanto, 2008; Hasan, 2002). Pengumpulan data menggunakan kuesioner yang dikirim ke pelanggan Starbucks yang telah mendaftar setidaknya selama satu bulan. Google form digunakan sebagai media untuk menyebarkan kuisioner. Untuk mencapai target responden yang tepat dan sesuai kebutuhan, disiapkan juga screening questions agar penyebarannya dapat memberikan hasil yang tepat.

Sebelum digunakan untuk pengambilan data sesungguhnya, dilakukan uji validitas dan uji reliabilitas atas kuesioner. Pengujian menggunakan 30 responden awal yang berkunjung ke Starbucks di kota Surabaya. Hasil uji validitas menunjukkan bahwa kuesioner dinilai valid karena nilai Pearson's product moment untuk setiap item pertanyaan adalah lebih besar dari $\alpha=0,05$ (Jogiyanto, 2008). Hasil uji reliabilitas menggunakan Alpha Cronbach juga menyatakan instrumen pengumpulan data penelitian ini sudah reliabel karena diperoleh nilai $0,984>0,70$ (Sujarweni, 2015; Indrawan \& Yuniawati, 2017). Proses kedua uji ini meng-gunakan software SPSS ver. 25.

\section{Metode Analisis Data}

Metode analisis data yang digunakan untuk menguji hipotesis dalam dimensi antara serta variabel laten yang diamati adalah Structural Equation Modeling Partial Least Square (SEM-PLS). Selanjutnya, model pengukuran (outer model) digunakan untuk menilai akurasi dan reliabilitas model. Analisis Faktor Konfirmatori (CFA) digunakan untuk menentukan apakah suatu variabel indikator benar-benar merupakan variabel laten yang diteliti (Haryono, 2017; Efendi \& Purnomo, 2012). Proses pengolahan data menggunakan software SmartPLS 3.0. 
Secara umum, analisis SEM melalui dua tahap (Indrawan \& Yuniawati, 2017; Latan \& Ghozali, 2012). Tahap pertama adalah penilaian variabel melalui model pengukuran (measurement model). Measurement model dalam PLS-SEM dievaluasi menggunakan $\mathrm{R}^{2}$ untuk mengukur tingkat varians di dalam perubahan variabel eksogen terhadap variabel endogen (Haryono, 2017; Abdillah \& Hartono, 2015). Semakin tinggi nilai $\mathrm{R}^{2}$ maka semakin baik derajat prediksi dari model penelitian.

Tahap kedua yaitu mengevaluasi model struktural atau inner model (structural measurement). Pengukuran ini menggunakan estimate for path coefficients, yaitu besaran signifikansi pengaruh antar variabel dengan faktor atau nilai kuantitas korelasi atau pengaruh konstruksi tersembunyi. Proses ini dilakukan melalui prosedur bootstrapping atau resampling method (Ghozali \& Latan, 2015; Haryono, 2017).

Untuk melakukan validasi atas model secara keseluruhan, digunakan uji Goodness of Fit Index (GoF) yang merupakan ukuran tunggal untuk memvalidasi hasil gabungan antara model pengukuran dengan model structural (Haryono, 2017). Nilai GoF ini diperoleh dari average communalities index dikalikan dengan nilai $\mathrm{R}^{2}$ model, dimana nilainya terbentang antara 0 sampai 1 dengan interpretasi nilai: 0,1 (GoF kecil); 0,25 (GoF moderate); dan, 0,36 (GoF besar).

\section{HASIL ANALISIS}

Dalam analisis verifikatif SEM-PLS terbentuk dua jenis model, yaitu model pengukuran (outer model) dan model struktural (inner model).

\section{Hasil Pengujian Outer Model}

Pengujian model pengukuran (outer model) digunakan untuk tujuan menentukan spesifikasi hubungan antara variabel laten dengan variabel manifesnya. Pengujian ini meliputi convergent validity, discriminant validity, dan reliability test.

Convergent validity berkaitan dengan prinsip bahwa variabel inventaris yang dibangun harus sangat berkorelasi. Dari total 32 item pernyataan, kesemuanya dinyatakan valid karena memiliki nilai outer loading lebih dari 0,7 dan nilai AVE > 0,5. Dengan demikian, seluruh variabel manifes dinyatakan telah memenuhi persyaratan convergent validity. Karenanya dapat dikatakan bahwa semua indikator yang digunakan pada penelitian ini sudah valid dalam mengukur masing-masing variabel latennya.

Discriminant validity dilihat melalui pengukuran cross loading factor dengan perbandingan AVE dan korelasi antar variabel dalam penelitian ini. Berdasarkan hasil analisis terangkum dalam Tabel 1 terlihat bahwa nilai akar AVE dari masing-masing variabel laten lebih tinggi dibandingkan nilai korelasi tertinggi variabel tersebut dengan variabel lainnya. Dengan demikian, dapat disimpulkan bahwa model yang digunakan dalam penelitian telah memiliki validitas diskriminan yang baik.

Reliability test adalah seberapa jauh sebuah hasil pengukuran pada objek yang sama namun dapat menghasilkan data yang sama. Berdasarkan hasil uji reliabilitas dalam Tabel 2 diidentifikasi bahwa nilai Composite Reability dan Cronbach's Alpha pada masingmasing variabel bernilai lebih 0,70 sehingga dapat dikatakan data memiliki reliabilitas tinggi. Dengan demikian, dapat dinyatakan bahwa semua pernyataan variabel dalam kuesioner penelitian ini dinyatakan reliabel atau konsisten.

\section{Hasil Pengujian Inner Model}

Pengukuran model struktural (inner model) bertujuan untuk melakukan pengujian mengenai pengaruh variabel laten lain. 
Tabel 1. Hasil Uji Discriminant Validity

\begin{tabular}{lcccc}
\hline \multicolumn{1}{c}{ Variabel Laten } & $\begin{array}{c}\text { Customer } \\
\text { Satisfaction }\end{array}$ & $\begin{array}{c}\text { Green } \\
\text { Marketing }\end{array}$ & $\begin{array}{c}\text { Loyalitas } \\
\text { Pelanggan }\end{array}$ & $\begin{array}{c}\text { Service } \\
\text { Quality }\end{array}$ \\
\hline Customer Satisfaction & 0,840 & & & \\
Green Marketing & 0,802 & 0,854 & & \\
Loyalitas Pelanggan & 0,815 & 0,838 & 0,851 & \\
Service Quality & 0,826 & 0,791 & 0,819 & 0,842 \\
\hline
\end{tabular}

Sumber: Data diolah, 2021.

Tabel 2. Hasil Uji Reliability Test

\begin{tabular}{lccccc}
\hline \multicolumn{1}{c}{ Variabel Laten } & $\begin{array}{c}\text { Composite } \\
\text { Reliability }\end{array}$ & $\begin{array}{c}\text { Nilai } \\
\text { Kritis }\end{array}$ & $\begin{array}{c}\text { Cronbach's } \\
\text { Alpha }\end{array}$ & $\begin{array}{c}\text { Nilai } \\
\text { Kritis }\end{array}$ & Kesimpulan \\
\hline Customer Satisfaction & 0,967 & & 0,963 & & Reliabel \\
Green Marketing & 0,969 & $>0,7$ & 0,966 & $>0,7$ & Reliabel \\
Loyalitas Pelanggan & 0,905 & & 0,861 & & Reliabel \\
Service Quality & 0,913 & & 0,872 & & Reliabel \\
\hline
\end{tabular}

Sumber: Data diolah, 2021.

Tabel 3. Hasil Determinasi Simultan

\begin{tabular}{lc}
\hline \multicolumn{1}{c}{ Variabel Laten } & $R$-Square \\
\hline Customer Satisfaction (Z) & 0,840 \\
Loyalitas Pelanggan (Y) & 0,815 \\
\hline
\end{tabular}

Sumber: Data diolah, 2021.

Berdasarkan Tabel 3 diperoleh nilai total kontribusi dari dua variabel eksogen terhadap variabel laten, yaitu customer satisfaction dan loyalitas pelanggan. Nilai $R$ Square adalah koefisien determinasi pada variabel endogen, dimana semakin tinggi nilai $R$-Square menunjukkan semakin baik model prediksi dari model penelitian yang diajukan.

Total kontribusi ( $R$-Square) dari green marketing dan service quality terhadap customer satisfaction adalah sebesar 0,741 yang berarti bahwa perubahan yang terjadi atas customer satisfaction dapat dijelaskan oleh kedua variabel eksogen dalam penelitian ini sebesar 74,1\%; sementara sisanya sebesar 25,9\% dijelaskan variabel-variabel lain yang tidak termasuk dalam model penelitian ini. Sementara itu, nilai total kontribusi ( $R$ Square) dari green marketing dan service quality terhadap loyalitas pelanggan sebesar 0,782 menyatakan perubahan yang terjadi atas loyalitas pelanggan dapat dijelaskan oleh kedua variabel eksogen dalam penelitian ini sebesar 78,2\%; sementara sisanya sebesar $21,8 \%$ dijelaskan variabel-variabel lain yang tidak termasuk dalam model penelitian ini.

Selanjutnya, total kontribusi itu dipilah menjadi nilai determinasi parsial dari masingmasing variabel eksogen atas tiap variabel endogen, yang ditunjukkan oleh hasil-hasil yang terangkum dalam Tabel 4 dan Tabel 5.

Tabel 4 menunjukkan besaran koefisien determinasi parsial dari green marketing (X1) dan service quality (X2) terhadap customer satisfaction (Z). Hasil empiris menunjukkan nilai kontribusi parsial dari green marketing ataupun service quality terhadap customer satisfaction masing-masing sebesar 0,317 dan 
0,424 yang berarti secara statistik customer satisfaction mampu dipengaruhi green marketing sebesar $31,7 \%$ serta service quality sebesar $42,4 \%$, dari total kontribusi $74,1 \%$.

Tabel 5 menunjukkan besaran koefisien determinasi parsial dari green marketing (X1), service quality (X2) serta customer satisfaction $(\mathrm{Z})$ terhadap loyalitas pelanggan (Y). Hasil empiris mengidentifikasi kontribusi parsial dari green marketing, service quality atau customer satisfaction terhadap loyalitas pelanggan masing-masing sebesar 0,343; 0,239 dan 0,200. Hasil ini berarti menyatakan loyalitas pelanggan mampu dipengaruhi green marketing sebesar 34,3\%, dipengaruhi service quality sebesar 23,9\%, serta dipengaruhi customer satisfaction sebesar 20,0\%, dari nilai total kontribusi sebesar 78,2\%.

Ketiga, hasil empiris yang diperoleh dalam penelitian ini menunjukkan besaran total kontribusi (total effect) atas hadirnya customer satisfaction sebagai intervening. Tabel 6 menunjukkan nilai total kontribusi dari green marketing terhadap loyalitas pelanggan melalui customer satisfaction adalah sebesar 0,517 yang berarti customer satisfaction mampu mengintervensi pengaruh green marketing terhadap loyalitas pelanggan mencapai $51,7 \%$; sedangkan sisanya sebesar $48,3 \%$ dijelaskan variabel-variabel lain yang tidak termasuk dalam model penelitian ini.

Tabel 6 juga menunjukkan nilai total kontribusi service quality terhadap loyalitas pelanggan melalui customer satisfaction sebesar 0,625 yang berarti bahwa customer satisfaction mampu mengintervensi pengaruh dari service quality atas loyalitas pelanggan mencapai $62,5 \%$; sedangkan sisanya sebesar $37,5 \%$ dijelaskan variabel-variabel lain yang tidak termasuk dalam model penelitian ini.

Tabel 4. Hasil Determinasi Parsial terhadap Variabel Z

\begin{tabular}{cccc}
\hline Pengaruh & Korelasi & Path & Parsial \\
\hline $\mathrm{X} 1 \longrightarrow \mathrm{Z}$ & 0,802 & 0,395 & 0,317 \\
$\mathrm{X} 2 \longrightarrow \mathrm{Z}$ & 0,826 & 0,513 & 0,424 \\
\hline & Total $R$-Square & & 0,741
\end{tabular}

Sumber: Data diolah, 2021.

Tabel 5. Hasil Determinasi Parsial terhadap Variabel Y

\begin{tabular}{cccc}
\hline Pengaruh & Korelasi & Path & Parsial \\
\hline $\mathrm{X} 1 \longrightarrow \mathrm{Y}$ & 0,838 & 0,410 & 0,343 \\
$\mathrm{X} 2 \longrightarrow \mathrm{Y}$ & 0,819 & 0,292 & 0,239 \\
$\mathrm{Z} \longrightarrow \mathrm{Y}$ & 0,815 & 0,246 & 0,200 \\
\hline & Total $R$-Square & & 0,782 \\
\hline
\end{tabular}

Sumber: Data diolah, 2021.

Tabel 6. Hasil Determinasi Total Efek Intervening

\begin{tabular}{|c|c|c|c|}
\hline \multirow{2}{*}{ Pengaruh } & \multicolumn{2}{|c|}{$R$-Square } & \multirow{2}{*}{ Total Effect } \\
\hline & $X \rightarrow Z$ & $X \rightarrow Z$ & \\
\hline $\mathrm{X} 1 \rightarrow \mathrm{Z} \rightarrow \mathrm{Y}$ & 0,317 & 0,200 & 0,517 \\
\hline $\mathrm{X} 2 \rightarrow \mathrm{Z} \rightarrow \mathrm{Y}$ & 0,815 & 0,200 & 0,625 \\
\hline
\end{tabular}

Sumber: Data diolah, 2021. 
Tabel 7. Hasil Pengujian Hipotesis

\begin{tabular}{|c|c|c|c|c|c|}
\hline Hipotesis & Variabel Laten & Koefisien Jalur & p-value & Nilai Kritis & Keputusan \\
\hline 1 & $\mathrm{X} 1 \longrightarrow \mathrm{Y}$ & 0,410 & 0,000 & & Signifikan \\
\hline 2 & $\mathrm{X} 2 \longrightarrow \mathrm{Y}$ & 0,292 & 0,000 & & Signifikan \\
\hline 3 & $\mathrm{X} 1 \longrightarrow \mathrm{Z}$ & 0,395 & 0,000 & & Signifikan \\
\hline 4 & $\mathrm{X} 2 \longrightarrow \mathrm{Z}$ & 0,513 & 0,000 & $<\alpha(0,05)$ & Signifikan \\
\hline 5 & $\mathrm{Z} \longrightarrow \mathrm{Y}$ & 0,246 & 0,001 & & Signifikan \\
\hline 6 & $\mathrm{X} 1 \rightarrow \mathrm{Z} \rightarrow \mathrm{Y}$ & 0,097 & 0,006 & & Signifikan \\
\hline 7 & $\mathrm{X} 2 \rightarrow \mathrm{Z} \rightarrow \mathrm{Y}$ & 0,126 & 0,002 & & Signifikan \\
\hline
\end{tabular}

Sumber: Data diolah, 2021.

\section{Hasil Pengujian Hipotesis}

Berdasarkan Tabel 7 diperoleh nilai koefisien jalur dari masing-masing variabel eksogen (yaitu: $\mathrm{X} 1=0,410 ; \mathrm{X} 2=0,292$; dan $\mathrm{Z}=0,246)$ terhadap variabel endogen adalah bernilai positif. Hasil ini diinterpretasikan bahwa jika salah satu variabel eksogen (yaitu: green marketing, service quality, dan customer satisfaction) mengalami kenaikan intensitas pemanfaatan dalam strategi, dengan asumsi jika variabel-variabel eksogen lain bernilai tetap, maka loyalitas pelanggan juga mengalami peningkatan. Sebaliknya, jika salah satu variabel eksogen ini mengalami penurunan intensitas pemanfaatan dalam strategi, dengan asumsi jika variabel-variabel eksogen lain bernilai tetap, maka loyalitas pelanggan juga akan mengalami penurunan.

Tabel 7 juga merangkum hasil-hasil uji hipotesis mengenai hubungan antara green marketing, service quality dan customer satisfaction dengan loyalitas pelanggan. Hasil-hasil yang diperoleh menunjukkan bahwa nilai $p$-value untuk setiap jalur analisis antara variabel eksogen dan variabel endogen adalah lebih kecil dari nilai $\alpha(=0,05)$. Dengan demikian dinyatakan bahwa pengaruh dari variabel-variabel eksogen terhadap variabel endogen, baik secara langsung maupun melalui variabel intervening, adalah bersifat signifikan. Artinya, semua hipotesis yang diajukan dalam penelitian ini (H1 sampai dengan H7) dapat dibuktikan atau dapat diterima kebenarannya.

\section{Pembahasan}

Hasil pertama yang diperoleh melalui penelitian ini memperoleh bahwa green marketing terbukti memiliki pengaruh secara positif dan signifikan atas loyalitas pelanggan. Hasil ini memunculkan pemahaman bahwa semakin baik strategi green marketing yang diaplikasikan perusahaan maka akan diikuti oleh semakin tingginya loyalitas pelanggan perusahaan tersebut (Martinez, 2015; Sari \& Setiawan, 2017; Jabeen \& Kavitha, 2020). Dalam penelitian ini dihubungkan dengan obyek analisis, maka bisa dinyatakan bahwa apabila tujuan Starbucks Coffee khususnya di Kota Surabaya untuk menghasilkan produk bersifat ramah lingkungan telah dapat memenuhi harapan dan kebutuhan pelanggan yang sadar lingkungan, maka menjadikan pelanggan itu menjadi semakin loyal kepada perusahaan tersebut.

Berkenaan dengan pengaruhnya atas customer satisfaction, hasil penelitian ini membuktikan strategi green marketing memiliki pengaruh yang positif signifikan. Hasil empiris bahwa green marketing berpengaruh positif dan signifikan terhadap customer satisfaction juga diperoleh Irkhamni \& Suharyono (2017), Parlan et al. (2016) dan Eneizan \& Wahab (2016). Dengan demikian, 
semakin baik penerapan green marketing dalam aktivitas bisnis milik Starbucks Coffee Kota Surabaya menurut persepsi pihak pelanggan, maka semakin tinggi kepuasan yang dirasakan pelanggan atas perusahaan yang bersangkutan.

Hasil empiris berikutnya membuktikan bahwa service quality berpengaruh positif dan signifikan terhadap loyalitas pelanggan. Service quality diukur melalui perbandingan antara harapan yang dimiliki pelanggan dengan realitas layanan yang mereka terima. Apabila realisasi layanan yang diterima dinilai lebih tinggi dari harapan yang mereka tetapkan sebelumnya, maka perusahaan yang bersangkutan dinilai memberikan pelayanan yang berkualitas tinggi (Fida et al., 2020; Narotama, 2019; Pereira et al., 2016; Malau, 2017; Kotler \& Keller, 2016). Dengan demikian, dapat diyatakan bahwa semakin baik penerapan service quality oleh Starbucks Coffee di Kota Surabaya maka akan diikuti oleh semakin tingginya loyalitas pelanggan pada perusahaan tersebut.

Service quality juga dibuktikan secara empiris oleh temuan penelitian ini bahwa memiliki pengaruh yang positif dan signifikan terhadap customer satisfaction. Temuan empiris ini memperluas hasil-hasil yang diperoleh sejumlah penelitian terdahulu seperti Fida et al. (2020), Jimanto (2014), Tjiptono (2014) serta Özkan (2019) yang juga menemukan service quality berpengaruh positif terhadap customer satisfaction. Berdasarkan temuan ini memperkuat argumen bahwa semakin berkualitas pelayanan yang diberikan perusahaan berdasarkan persepsi pelanggannya maka semakin tinggi derajat kepuasan yang dirasakan oleh pelanggan tersebut terhadap perusahaan bersangkutan.

Hasil empiris berikutnya yang diperoleh di dalam penelitian ini adalah customer satisfaction terbukti berpengaruh positif dan signifikan terhadap kualitas pelayanan. Hasil ini memperluas temuan empiris milik sejumlah peneliti terdahulu seperti Özkan et al., 2020; Alfin \& Nurdin, 2017 dan Nuraeni et al., 2019. Hasil penelitian ini sebaliknya bertentangan dengan temuan studi Soelasih (2017) yang berargumen bahwa customer satisfaction tidak berpengaruh terhadap loyalitas pelanggan. Berdasarkan temuan empiris penelitian ini maka dinyatakan jika pelanggan menilai bahwa produk perusahaan memberikan realisasi nilai kepuasan yang lebih tinggi dibandingkan harapan yang dimilikinya atas produk tersebut, maka ia akan menjadi loyal serta mengarah pada terciptanya ikatan emosional yang kuat dan komitmen jangka panjang atas produk perusahaan tersebut.

Ketika berikutnya diposisikan sebagai variabel intervening, hasil penelitian ini membuktikan bahwa customer satisfaction mampu memberikan efek intervensi yang memperkuat pengaruh baik dari strategi green marketing maupun service quality dalam upaya mempertinggi sikap loyal pelanggan kepada perusahaan. Berdasarkan hasil ini maka dinyatakan bahwa perusahaan akan berhasil menerapkan strategi green marketing ataupun service quality dalam upaya meningkatkan loyalitas pelanggan jika sebelumnya mampu menciptakan rasa puas dalam diri pelanggannya setelah mengkonsumsi produk barang dan/atau jasa pelayanan yang diberikan perusahaan yang bersangkutan.

\section{SIMPULAN}

Hasil penelitian ini menyimpulkan bahwa green marketing memiliki pengaruh langsung yang positif dan signifikan baik terhadap customer satisfaction dan loyalitas pelanggan; service quality memiliki pengaruh langsung yang positif dan signifikan baik terhadap customer satisfaction dan loyalitas pelanggan; serta, customer satisfaction 
memiliki pengaruh langsung yang positif dan signifikan terhadap loyalitas pelanggan.

Saat diperlakukan sebagai variabel intervening, customer satisifaction terbukti mampu memperkuat pengaruh positif dari green marketing atau dari service quality terhadap loyalitas pelanggan. Hasil ini menyimpulkan bahwa agar strategi green marketing ataupun service quality yang diterapkan perusahaan menjadi lebih mampu menciptakan sikap loyalitas yang tinggi dari para pelanggannya jika perusahaan yang bersangkutan telah mampu memberikan rasa kepuasan di dalam diri para pelanggannya tersebut.

Peningkatan konsep dari interior cafe dengan mengutamakan physical environment ramah lingkungan supaya pelanggan merasa aman serta tidak asing bila terletak di Starbucks Coffee serta mempertahankan green marketing yang ada dan akan terus mencari inovasi baru dalam promosi melalui green marketing sebagai strategi merupakan saran yang dapat diberikan agar loyalitas pelanggan dan customer satisfaction dapat bertambah.

Bagi penelitian selanjutnya, pelaksanaan penelitian pada industri lain yang sejenis dengan memakai variabel yang sama sehingga hasilnya dapat dijadikan sebagai bahan perbandingan. Selain itu, pelaksanaan studi mengenai green marketing dan service quality menggunakan teori dari para ahli yang berbeda dan terbaru diekspektasikan akan dapat menambah khazanah ilmu pengetahuan dalam bidang pemasaran.

\section{REFERENSI}

Abdillah, W., \& Hartono. (2015). Partial least square (PLS). Andi.

Alfin, M. R., \& Nurdin, S. (2017). Pengaruh store atmosphere pada kepuasan pelanggan yang berimplikasi pada loyalitas pelanggan. Ecodemica, 1(2): 249-258. doi: 10.31294/Jeco.V1i2.
2277.

Alhamad, A. M., Junoh, M. Z. B. M., Ahmad, T. S. B. T., \& Eneizan, B. (2019). Green marketing strategies: Theoretical approach. American Journal of Economics and Business Management, 2(2), 77-94. doi: 10.31150/ajebm.Vol2. Iss2.72.

Ambari, M. (2020). Tekad Indonesia bersihkan sampah plastik di laut. Situs Berita Lingkungan. Edisi tanggal 27 April. Retrieved from https://www.mongabay. co.id/2020/04/27/tekad-indonesiabersihkan-sampahplastik-di-laut/.

Bennett, R., \& Bove, L. (2002) Identifying the key issues for measuring loyalty. Australian Journal of Market Research, 9(2), 27-44. Retrieved from https:// eprints.qut.edu.au/10634/.

BPS. (2019). Lingkungan hidup Indonesia 2019; Hutan dan perubahan iklim. Badan Pusat Statistik.

Browne, M. A., Hentschel, B. T., Halpern, B., \& Kaparanagioti, H. K. (2013). Volunteer cleaners negotiate a Bulgarian reservoir jammed with plastics. Classify Plastic Waste as hazardous.

Chandra, W. (2020. Monster sampah berkeliaran di Makassar serukan bahaya sampah plastik. Situs Berita Lingkungan. Edisi tanggal 23 November. Retrieved from https://www.mongabay. co.id/2020/11/13/monster-sampahberkeliaran-di-makassar-serukanbahaya-sampah-plastik/

Dohong, A. (2020). Hadapi dampak perubahan iklim, Wamen LHK harapkan sinergi kebijakan pemerintah pusat dan daerah. Kementerian Lingkungan Hidup dan Kehutanan. Edisi tanggal 22 November. Retrieved from http://ppid.menlhk.go.id/siaran_ pers/browse/2740.

Efendi, M. M., \& Purnomo, J. D. T. (2012). Analisis faktor konfirmatori untuk mengetahui kesadaran berlalu lintas pengendara sepeda motor di Surabaya Timur. Jurnal Sains dan Seni ITS, 1(1), 
106-111. doi: 10.12962/j23373520. v1i1.965.

Eneizan, B. M., \& Wahab, K. A. (2016). Effect of green marketing strategy on customer satisfaction in Jordan. Arabian Journal of Business and Management Review (OMAN Chapter), 5(9), 34-40. doi: 10.12816/0027129.

Fida, B. A., Ahmed, U., Al-Balushi, Y., \& Singh, D. (2020). Impact of service quality on customer loyalty and customer satisfaction in Islamic banks in the Sultanate of Oman. SAGE Open, 10(2), 1-10. doi: 10.1177/2158244020 919517.

Ghozali, I., \& Latan, H. (2015). Konsep, teknik, aplikasi menggunakan Smart PLS 3.0 untuk penelitian empiris. BP Undip.

Grant, J. (2007). The green marketing manifesto. Wiley.

Haryono, P. S. (2017). Metode SEM untuk penelitian manajemen AMOS LISREL PLS. PT. Luxima Metro Media.

Hasan, I. L. (2002). Pokok-pokok materi metodologi penelitian dan aplikasinya. Ghalia Indonesia.

Indrawan, P. R., \& Yuniawati, P. P. (2017). Metodologi penelitian kuantitatif, kualitatif, dan campuran untuk manajemen, pembangunan, dan pendidikan. Refika Aditama.

Indrawati. (2015). Metode penelitian manajemen dan bisnis. Refika Aditama.

Irkhamni, D. A., \& Suharyono, S. (2017). Pengaruh penerapan green marketing terhadap kepuasan dan loyalitas pelanggan (Survei pada pelanggan treatment Naavagreen natural skin care cabang Malang). Jurnal Administrasi Bisnis, 50(3), 33-39.

Irwansyah, A. (2015). Analisis program corporate social marketing, pengetahuan konsumen dan reputasi perusahaaan dalam menciptakan green consumerism (Program tumbler Starbucks). Jurnal Ilmiah Universitas Batanghari Jambi, 15(3), 52-56. doi: 10.33087/jiubj.v15i3. 149.
Jabeen, S. S., \& Kavitha, M. (2020). Effect of green marketing strategies on customer loyalty effect of green marketing strategies on customer loyalty. Journal of Xi'an University of Architecture \& Technology, 12(9), 14-20. doi.org/10. 37896/JXAT12.09/2852.

Jimanto, R. B. (2014). Pengaruh service quality terhadap loyalitas pelanggan dengan customer satisfaction sebagai variabel intervening pada ritel bioskop The Premiere Surabaya. Jurnal Strategi Pemasaran, 2(1), 1-7. Retrieved from: http://publication.petra.ac.id/index.php/ manajemen-pemasaran/article/view/ 1407.

Jogiyanto, P. (2008). Metodologi penelitian sistem informasi. CV. Andi Offset.

Kotler, P., \& Armstrong, G. (2017). Principles of marketing $\left(17^{\text {th }}\right.$ edition). Pearson.

Kotler, P., \& Keller, K. L. (2016). Marketing management $\left(15^{\text {th }}\right.$ Edition). Pearson Prentice-Hall.

Latan, H., \& Ghozali, I. (2012). Partial least square path WarpPLS 2.0. Badan Penerbit Universitas Diponegoro.

Malau, H. (2017). Manajemen pemasaran. CV. Alfabeta.

Martinez, P. (2015). Customer loyalty: Exploring its antecedents from a green marketing perspective. International Journal of Contemporary Hospitality Management, 27(5), 896-917. doi: 10.1108/IJCHM-03-2014-0115.

Narotama, A. (2019). The effect of service quality on customer loyalty with brand images and customer satisfaction as mediation. Jurnal Manajemen dan Kewirausahaan, 7(1), 86-93. doi: 10.26905/jmdk.v7i1.2692.

Nuraeni, R., Eldine, A., \& Muniroh, L. (2019). Pengaruh kualitas pelayanan dan kepuasan pelanggan terhadap loyalitas pelanggan. Manager, 2(4), 487-493. doi: 10.32832/manager.v2i4. 3795. 
Özkan, P., Süer, S., Keser, İ. K., \& Kocakoç, I. D. (2020). The effect of service quality and customer satisfaction on customer loyalty: The mediation of perceived value of services, corporate image, and corporate reputation. International Journal of Bank Marketing, 38(2), 384-405. doi: 10.1108/IJBM-03-2019-0096.

Parasuraman, A., Zeithaml, V. A., \& Berry, L. L. (1985). A conceptual model of service quality and its implications for future research. Journal of Marketing, 49(4), 41-45. doi: 10.1177/00222429 8504900403.

Parlan, A. V., Kusumawati, A., \& Mawardi, M. K. (2016). The effect of green marketing mix on purchase decision and customer satisfaction (Study on independent consultant of JAFRA Cosmetics Indonesia in Malang). Jurnal Administrasi Bisnis, 39(1), 172-178. Retrieved from http://administrasi bisnis.studentjournal.ub.ac.id/index.php /jab/article/view/1548.

Pereira, D., Giantari, N. G. K., \& Sukaatmadja, P. G. (2016). Pengaruh service quality terhadap satisfaction dan customer loyalty Koperasi Dadirah di Dili Timor-Leste. E-Jurnal Ekonomi dan Bisnis Universitas Udayana, 5(3), 455-488. Retrieved from https://ojs. unud.ac.id/index.php/EEB/article/view/ 15164.

Peter, J. P., \& Olson, J. C. (2010). Consumer behavior \& marketing strategy $\left(9^{\text {th }}\right.$ Edition). McGraw-Hill/Irwin.

Priansa, D. J. (2017). Perilaku konsumen dalam persaingan bisnis kontemporer. CV. Alfabeta.

Rasyadi, M. A. (2019). Sampah kemasan makanan dan minuman mendominasi. Greenpeace Indonesia. Edisi tanggal 14 November. Retrieved from https:// www.greenpeace.org/indonesia/cerita/4 238/sampah-kemasan-makanan-danminuman-mendominasi/.

Saini, S., \& Singh, J. (2020). A link between attitudinal and behavioral loyalty of service customers. Business Perspectives and Research, 8(2), 205215. doi: $10.1177 / 2278533719887452$.

Sandeen, C. (2009). It's not easy being green: Green marketing and environmental consumerism in continuing higher education. Continuing Higher Education Review, 73, 93-113. Retrieved from https://eric.ed.gov/?id= EJ903455.

Sari, I. G. A. W, \& Setiawan, P. Y. (2019). Pengaruh green marketing dan packaging terhadap brand image dan loyalitas pelanggan pada konsumen Starbucks Coffee. E-Jurnal Manajemen Unud, 6(7), 3820-2849. Retrieved from https://jab.polinema.ac.id/index.php/jab /article/view/300.

Soelasih, Y. (2017). Kepuasan konsumen tidak selalu membentuk loyalitas. Jurnal Manajemen, 21(3), 363-380. doi: 10.24912/jm.v21i3.257.

Starbucks, C. (2020). C.A.F.E. practices: Starbucks approach to ethically sourcing coffee. Starbucks Stories \& News. Edisi tanggal 28 Februari. Retrieved from https://stories.starbucks. com/press/2020/cafe-practicesstarbucks-approachto-ethicallysourcing-coffee/.

Sugiyono. (2018). Metode penelitian kuantitatif, kualitatif, dan $R \& D$. Alfabeta.

Sujarweni, V. W. (2015). Metodologi penelitian bisnis ekonomi. Pustaka Baru.

Sumarwan, U., Jauzi, A., Karno, B. N., Mawardi, P., \& Nugroho, W. (2011). Riset pemasaran dan konsumen. PT. Penerbit IPB Press.

Tjiptono, F. (2014). Pemasaran jasa Prinsip, penerapan, dan penelitian. CV. Andi Offset.

Tsai, D., \& Chen, C. F. (2007). How destination image and evaluative factors affect behavioral intentions? Tourism Management, 28(4), 11151122. doi: 10.1016/j.tourman.2006. 07.007 . 
Wicaksana, G. E. G. (2014). Analisis loyalitas konsumen Starbucks terhadap brand Starbucks di Surabaya. Commonline Departement Komunikasi, 3(2), 132141. Retrieved from https://repository. unair.ac.id/15762/.
Zeithaml, V. A., Berry, L. L., \& Parasuraman, A. (1996). The behavioral consequen ces of service quality. Journal of Marketing, 60(2), 31-46. doi: 10.2307/1251929.

Zikmund, W. G., Babiin, B. J., Carr, J. C., \& Griffin, M. (2010). Business research methods $\left(8^{\text {th }} \mathrm{ed}\right)$. Cengage Learning. 